\title{
PRODUCTIVE PERFORMANCE OF SIMMENTAL DAIRY COWS SUPPLEMENTED WITHRICINOLEIC ACID FROM CASTOR OIL
}

\author{
DESEMPENHO PRODUTIVO DE VACAS LEITEIRAS SIMENTAL SUPLEMENTADAS \\ COM ÁCIDO RICINOLEICO EXTRAIDO DO ÓLEO DE MAMONA
}

\author{
Gandra,J.R. ${ }^{2 *}$; Nunes Gil, P.C. ${ }^{1}$; Gandra, E.R.S. ${ }^{3}$; Vale, T.A. del ${ }^{1}$; Barletta, R.V. ${ }^{1}$; \\ Zanferari, F. ${ }^{1}$; Ferreira de Jesus, E. ${ }^{4}$; Takiya, C.S. ${ }^{1}$; Mingoti, R.D. ${ }^{1}$; Almeida, G.F. \\ Paiva, P.G. ${ }^{4}$ and Gobesso, A.A.O. ${ }^{1}$
}

\begin{abstract}
${ }^{1}$ Departament of Nutrition and Animal Production. FMVZ/USP. Pirassununga-SP. Brazil. 2Departament of Animal Science. FCA/UFGD. Dourados-MS. Brazil. *jeffersongandra@ufgd.edu.br ${ }^{3}$ SENAGAN. Animal Nutrition. Nova Andradina-MS. Brazil. ${ }^{4}$ Departament of Animal Science. FCAV/UNESP. Jaboticabal-SP. Brazil.
\end{abstract}

\section{AdDitionAL KEYWORDS}

Blood cells. Functional oil. Milk yield. Plasma metabolites.

\section{SUMMARY}

The aim of this study was to evaluate the performance and blood parameters of Simmental dairy cows, supplemented with $2 \mathrm{~g} /$ day of ricinoleic acid (RA) in diet. Forty Simmental dairy cows in mid lactation, individually housed in stable type tiestall, were used. The animals were randomly assigned to two treatments: 0 or $2 \mathrm{~g}$ of RA/animal/ day. The experimental period consisted of 42 days divided into two 21-day. It was observed reduction in dry matter intake (DMI), increased milk, fat and FCM (fat corrected milk) yield, as well as increased of fat content of milk in cows that received RA in diets. No effects were observed for red and white blood cells and blood metabolites. Supplementation of RA improves performance of dairy cows in mid lactation.

\section{RESUMO}

O objetivo deste estudo foi avaliar o desempenho e os parâmetros sanguíneos de vacas leiteiras simental suplementadas com $2 \mathrm{~g} /$ dia de ácido ricinoleico (AR) na dieta. Foram usadas 40 vacas leiteiras da raça Simental no meio da lactação, alojados individualmente em tie-stall. Os animais foram divididos aleatoriamente em dois tratamentos: 0 ou $2 \mathrm{~g}$ de RA / animal / dia, fornecido via concentrados. O período experimental consistiu

\section{PaLAVRAS ChaVE ADICIONAIS}

Células sanguíneas. Óleo funcional. Produção de leite. Metabólitos plasmáticos.

de 42 dias, divididos em dois períodos de 21 dias. Foi observada a redução no consumo de matéria seca (CMS), aumento da produção de leite, gordura e produção corrigida $3,5 \%$, bem como um aumento do teor de gordura do leite em vacas que receberam AR na dietas. Nenhum efeito foi observado para os glóbulos vermelhos e brancos e metabólitos no sangue. Suplementação de AR melhorou o desempenho de vacas leiteiras no terço médio de lactação.

\section{INTRODUCTION}

The production of milk solids is gaining role in world of dairy farming, by the fact of dairy industries seeking greater efficiency in the production of dairy products. Within a dairy herd several factors can alter the milk solids (protein, fat and lactose). Factors which affect milk composition include genetics, stage of lactation, and level of milk production age of cow, environment, disease (e.g. mastitis) and nutrition. Of the variation in milk composition, 55 percent is due to heredity and 45 percent is due to environmental factors, such as feeding (Allen, 2000). 
The composition of milk solids can be handled by nutritional alternatives, mainly, manipulating the quality and quantity of fiber and addition of additives modulators of rumen fermentation. Among the modulators of rumen fermentation ionophores are disseminated over 50 years, with a history of success in reducing losses metabolic hence provide a better rumen sanity and positive results in the increase in milk protein content of and inconclusive results in milk fat (Gandra et al., 2010). However, under the law, ionophores are classified as antibiotics, which makes their use is increasingly criticized by consumer society.

Due to the possible consequences of prolonged use of antibiotics in animal feed on the development of resistant pathogens and the possible transfer of the waste products of animal origin, the European Union, based on the precautionary principle, banned the use of ionophores since January 2006. This has aroused increasing scientific interest for alternatives that mimic the effects of ionophores in control specific microbial populations to modulate ruminal fermentation. Among the various options, secondary plant compounds have great potential use, highlighting the essential oils.

Essential oils are organic compounds represented by a mixture of aromatic terpenoids, and lipophilic fluids obtained from different plant parts such as leaves, roots, stems, fruits, seeds, or more one part extracted by steam distillation processes or volatile solvents such as methanol and hydroxy-acetone (Coneglian, 2009). The mode of action of essential oils in ruminants is still not been completely elucidated. However some hypotheses that have been lifted: control of pathogens by antimicrobial activity, antioxidant activity, improves digestion by stimulating enzyme activity and morphometry of organs (Coneglian, 2009).

Many essential oils have been studied for this purpose; however, standing out among them is castor oil, which is obtained by pressing the seeds. It contains $90 \%$ of ricinoleic acid (RA), which gives the oil its unique features, enabling a wide range of industrial use. The cultivation of castor beans is thus important for the economic potential of Brazil. RA is very similar to oleic acid, the only difference being a hydroxyl group present in RA and absent in oleic acid. For this reason, RA is also called hydroxyoleic acid (Gandra et al., 2012).

Although the toxicity of the castor bean has been known since ancient times, castor oil is not toxic because ricin, a toxic protein present in the seeds, is not lipid soluble, so the toxic component is restricted only to the castor bean. Ricin specifically and irreversibly inactivates eukaryotic ribosomes, preventing protein synthesis (Dorman and Deans, 2000). The oil obtained by pressing the seeds is a polymer precursor and a solution of RA esters, and is known as castor oil (Ferreira et al., 2002).

The detergent derived from castor oil, in turn, shows antimicrobial properties in the treatment of necrosis of tooth pulp; its bactericidal activity is similar to sodium hypochlorite (Ferreira et al., 2002).

Given the antimicrobial properties of RA and growing demand for non-antibiotic supplements for ruminant nutrition, it has been proposed to include RA in the diet of dairy cows, in order to observe its effects as a possible modulator of ruminal fermentation on the basis of possible performance improvement without harm to animal health. In order to explore the antimicrobial properties of RA, the objective of this study was to evaluate the dry matter intake, milk yield and composition and blood parameters of Simmental dairy cow supplemented with $2 \mathrm{~g}$ /day of RA in the diet, in according with recommendations of (Gandra et al., 2012).

\section{MATERIAL AND METHODS}

\section{ANIMALS AND MANAGEMENT}

Forty Simmental dairy cows in mid lactation were used, with yield of $25.6 \pm 3.4 \mathrm{~kg} /$ 
cow/day and weight $563 \pm 38 \mathrm{~kg}$, individually housed in stable type tie-stall. The animals were randomly assigned to two treatments: $0 \mathrm{~g} \mathrm{RA} / \mathrm{animal} / \mathrm{day}$ or $2 \mathrm{~g}$ of RA/animal/day directly in the mouth in the morning, just after milking for soft capsules.

The experiment was conducted in a completely randomized design and consisted of 42 days divided into two 21-day. Diets were formulated according to NRC (2001), meeting the nutritional requirements for this stage of lactation, contains roughage:concentrate ratio of $55: 45$. The roughage used was corn silage. The respective diets, water and mineral salts were provided ad libitum throughout the experimental period. The animals were fed twice a day, morning and afternoon.

Ricinoleic acid (RA) is produced from castor oil, which is obtained by pressing the seeds. The oil is then complexed with a polymer to give a solid consistency to the RA.

Before the rations were given to the animals, the orts from the feeder were weighed daily in order to estimate dry matter intake. The animals were fed according to

Table I. Ingredient composition of the concentrate and the experimental diet. (Composição dos ingredients do concentrado e da dieta experimental).

\begin{tabular}{lcc}
\hline Ingredients (\% DM) & Concentrate & Diets \\
\hline Maize silage & - & 55.00 \\
Maize meal & 52.14 & 21.9 \\
Soyabean meal & 39.1 & 16.42 \\
Urea & 1.74 & 0.73 \\
Sulfate of ammonia & 0.12 & 0.05 \\
Sodium bicarbonate & 1.48 & 0.62 \\
Magnesium oxide & 0.05 & 0.02 \\
Mineral mix ${ }^{1}$ & 4,67 & 1.96 \\
Limestone & 0.28 & 0.10 \\
Salt & 0.48 & 0.20 \\
\hline
\end{tabular}

${ }^{1}$ Composition per kg of mineral mix: Ca: $180 \mathrm{~g} ; \mathrm{P}: 90$ g; Mg: 20g; S: 20 g; Na: 100 g; Zn: 3000 mg; Cu: 1000 mg; Mn: 1250mg; Fe: 2000 mg; Co: 200 mg; I: 90 mg; Se: 36 mg; F: 900 mg (máx.).
Table II. Nutritional composition (\% dry matter) of the concentrate, maize silage and experimental diet. (Composição nutricional (\% da materia seca) do concentrado, da silage de milho e da dieta experimental).

\begin{tabular}{lccr}
\hline Nutrients & Concentrate Silage & Diet \\
\hline Dry matter, \% & 89.42 & 28.96 & 54.3 \\
Organic matter & 89.98 & 94.47 & 92.58 \\
Crude protein & 27.73 & 8.82 & 16.77 \\
Fatty acids & 2.9 & 2.91 & 2.90 \\
Total carbohydrate & 61.34 & 82.74 & 72.91 \\
Neutral detergent fiber & 9.89 & 53.2 & 35.01 \\
Non-fibrous carbohydrate & 55.96 & 29.54 & 40.64 \\
Acid detergent fiber & 7.94 & 43.69 & 28.68 \\
Lignin $_{\text {Ash }}$ & 1.07 & 5.44 & 3.61 \\
Total digestible nutrients $^{1}$ & 82.48 & 62.53 & 7.42 \\
& & & \\
\hline
\end{tabular}

${ }^{1}$ Estimated according to NRC (2001).

the dry matter intake of the previous day in order to maintain the percentage of daily orts between $5 \%$ and $10 \%$ of the supplied diets (tables I and II).

\section{SAMPLE COLLECTION AND ANALYSIS}

On days 14-21 of the experimental periods, orts, silage, and concentrate ingredients were collected for analyses of dry matter (DM), organic matter (OM), ash, crude protein (CP), fatty acids (FA), and lignin in accordance with the methods described by AOAC (2000). Crude protein (CP) was obtained by multiplying the total nitrogen content by 6.25 .

Neutral detergent fibre (NDF) and acid detergent fibre (ADF) contents were obtained according to the method described by AOAC (2000), using $\alpha$-amylase without the addition of sodium sulphite in the determination of NDF in an AnkonSystem ${ }^{\circledR}$.

The total carbohydrates (TC) and total digestible nutrients (TDN) were calculated according to NRC (2001):

$\mathrm{CT}=100-(\% \mathrm{CP}+\% \mathrm{FA}+\% a \mathrm{sh}) ;$ 
$T D N=d C P+d N D F+(d F A \times 2.25)+d N F C$.

The levels of non-fibrous carbohydrates (NFC) were estimated according to NRC (2001):

$\mathrm{NFC}=100-[(\% \mathrm{CP}-\% \mathrm{CP}$ urea $+\%$ urea $)+\% \mathrm{FA}+$ $\%$ NDF + \%ash]

On days 0 and 21 of each experimental period, before the supply of the diets and after the milking in the morning, the animals were weighed and blood samples were collected by vein or coccygeal artery puncture.

Blood samples were collected (vacutainer) for measurement of blood parameters: total protein, albumin, urea, aspartate aminotransferase (AST), gamma glutamyl transferase (GGT), and alkaline phosphatase (ALP) in plasma in addition to the haemogram (red series), that measured erythrocytes, haematocrit, haemoglobin, MCV (mean corpuscular volume), $\mathrm{MCH}$ (mean corpuscular haemoglobin), MCHC (mean corpuscular haemoglobin concentration), and WBC (white series) that measured leucocytes, neutrophils, lymphocytes, eosinophils, monocytes, basophils, and fibrinogen.

Immediately after collection, the samples were cooled and centrifuged at $2000 \mathrm{~g}$ for 15 min to separate the serum or plasma, and then stored at $2{ }^{\circ} \mathrm{C}$ until the laboratory procedure, using commercially available kits (LABORLAB ${ }^{\circledR}$ and CELM ${ }^{\circledR}$ ) for measuring total protein, albumin, urea, AST, GGT, and ALP. Enzymatic colorimetric and end-point methods were used; the readings were performed in an automated blood biochemistry analyzer (CELMSBA-200®). Blood samples collected for haemograms were analysed fresh on the same day of weighing animals and biochemical analyses.

Cows were mechanically milked twice a day, at $06: 30$ and at 15:30, being the milk production recorded daily throughout the experimental period. Milk production was corrected for $3.5 \%$ of fat (FCM) according to formula of NRC (2001):

$\mathrm{FCM}=(0.432+0.1625 *$ milk fat content $){ }^{*} \mathrm{~kg}$ of milk

and contents of milk fat, protein, lactose were determined in fresh.

Milk samples were collected on days 19 , 20,21 of each experimental period, through the collection cup $50 \mathrm{ml}$ attached to the milking, $60 \%$ during morning milking and $40 \%$ in the afternoon milking. We used the average of three days of collection. The samples were stored in plastic bottles, maintained from 2 to $6^{\circ} \mathrm{C}$ and sent for analysis to obtain milk composition performed at the Clinic of Milk ESALQ-USP. The total concentration of crude protein, fat, lactose, total solids (TS) and dry extract (DE), somatic cell count (SCC) and total bacterial count (TBC), according to the methodology described by the International Dairy Federation(1996).

\section{STATISTICAL ANALYSIS}

The data were analysed by PROC MIXED according to the following model:

$$
Y i j=i ̀+D i+T j+T j(D j)+e i j
$$

where:

Yij= dependent variable;

$\grave{i}=$ overall mean;

$\mathrm{Di}=$ effect of diet $(\mathrm{i}=1-2)$;

$\mathrm{Tj}=$ effect of days in confinement;

$\mathrm{Di}(\mathrm{Tj})=$ effect of interaction between diet and day of confinement;

eij= error

The calculated degrees of freedom were performed according to the Satterth Waitte method (ddfm - satterth). The data were subjected to analysis of variance by the command PROC MIXED of SAS version 9.0 (SAS, 2004). Means were adjusted by LSMEANS and analyzed by Tukey test adjusted PROC MIXED. The data obtained at baseline were used as covariates in the statistical model, with $p<0.05$. The function pdiff of PROC MIXED was used for ana- 
lysis of interactions, adopting $\mathrm{p}<0.05$.

\section{RESULTS}

\section{Performance}

With supplementation with RA, it was observed reduction in dry matter intake (DMI), increased milk, fat and FCM yields, and reduced DE $(\mathrm{p}<0.05)$. The reduction in DMI was $11.70 \%$, increase in milk yield was $7.52 \%$ and $11.26 \%$ for FCM when comparing the diet supplemented with RA with diet control (table III).

The experimental period (time) influenced $(\mathrm{p}<0.05)$ dry matter intake, milk yield, fat correct milk, total solids, dry extract, total bacteria count, yield and levels of protein and fat, except SCC. Interaction was observed $(\mathrm{p}<0.05)$ between the RA and time for milk and protein yield, as well as levels of protein and fat. Milk yield increased with the over time when if using the RA in the diet. For the control diet was observed reduction in milk yield, starting $21^{\text {st }}$ day of supplementation, resulting in a significant difference $(\mathrm{p}<0.05)$ between treatments (figure 1A).

It was observed an increase protein content during trial for the control diet. This increase was not observed in the RA diet, so that the difference between the levels of milk protein between diets were significant $(p<0.05)$ starting $21^{\circ}$ day of supplementation (figure 1B). For protein yield, however, no difference was observed $(\mathrm{p}>0.05)$ between diets, only effect of time.

Associated with increased protein content there was a reduction of the milk fat content from cows fed the control diet, not observed for diet RA. This reduction caused significant difference $(p<0.05)$ between the diets starting $21^{\circ}$ day of supplementation (figure 1C).

\section{HaEMOgRam AND LEUCOGRAM}

Among the hematological parameters

Table III. Productive performance. (Desempenho produtivo).

\begin{tabular}{|c|c|c|c|c|c|c|}
\hline \multirow[t]{2}{*}{ Indices } & \multicolumn{2}{|c|}{ Diet $^{1}$} & \multirow[t]{2}{*}{ SEM } & \multicolumn{3}{|c|}{$p$ value } \\
\hline & Control & RA & & RA & Time & $\mathrm{RA}^{*}$ Time \\
\hline \multicolumn{7}{|l|}{$\mathrm{kg} / \mathrm{day}$} \\
\hline Dry matter intake & 18.38 & 16.23 & 0.18 & 0.034 & $<0.001$ & 0.563 \\
\hline Mik yield & 22.47 & 24.16 & 0.64 & 0.006 & $<0.001$ & 0.002 \\
\hline Fat corrected milk, $3.5 \%$ & 23.44 & 26.08 & 0.75 & 0.020 & $<0.001$ & 0.841 \\
\hline Fat & 0.82 & 0.97 & 0.03 & 0.008 & $<0.001$ & 0.142 \\
\hline Protein & 0.76 & 0.72 & 0.01 & 0.458 & $<0.001$ & 0.007 \\
\hline Lactose & 1.02 & 1.10 & 0.04 & 0.674 & $<0.001$ & 0.765 \\
\hline Fat,\% & 3.85 & 3.91 & 0.10 & 0.665 & $<0.001$ & $<0.001$ \\
\hline Protein, $\%$ & 3.23 & 3.15 & 0.01 & 0.458 & 0.007 & $<0.001$ \\
\hline Lactose,\% & 4.56 & 4.55 & 0.06 & 0.897 & 0.759 & 0.645 \\
\hline T S,\% & 13.07 & 13.07 & 0.09 & 0.997 & $<0.001$ & 0.002 \\
\hline $\mathrm{DE}, \%$ & 9.31 & 9.09 & 0.04 & 0.006 & 0.002 & 0.051 \\
\hline \multicolumn{7}{|l|}{$10^{3} \mathrm{CFM} / \mathrm{mL}$} \\
\hline SCC & 1140 & 998 & - & 0.676 & 0.125 & 0.283 \\
\hline TBC & 416 & 521 & - & 0.598 & 0.046 & 0.868 \\
\hline
\end{tabular}

${ }^{1}$ Supplement of $2 \mathrm{~g} /$ day of ricinoleic acid from of castor oil (Ricinus communis L.) per animal/day in total diet; $\mathrm{TS}=$ Total solids; $\mathrm{DE}=$ dry extract; $\mathrm{CFU}=$ Colony forming units; $\mathrm{SCC}=$ somatic cell count; $\mathrm{TBC}=$ total bacteria count; RA= Ricinoleic acid. 
evaluated were observed decrease in the concentration of $\mathrm{MCHC}$ and absolute values of eosinophil $(\mathrm{p}<0.05)$ for RA compared to control diet. The absolute values of eosinophil were similar at baseline between diets and it was observed an increase
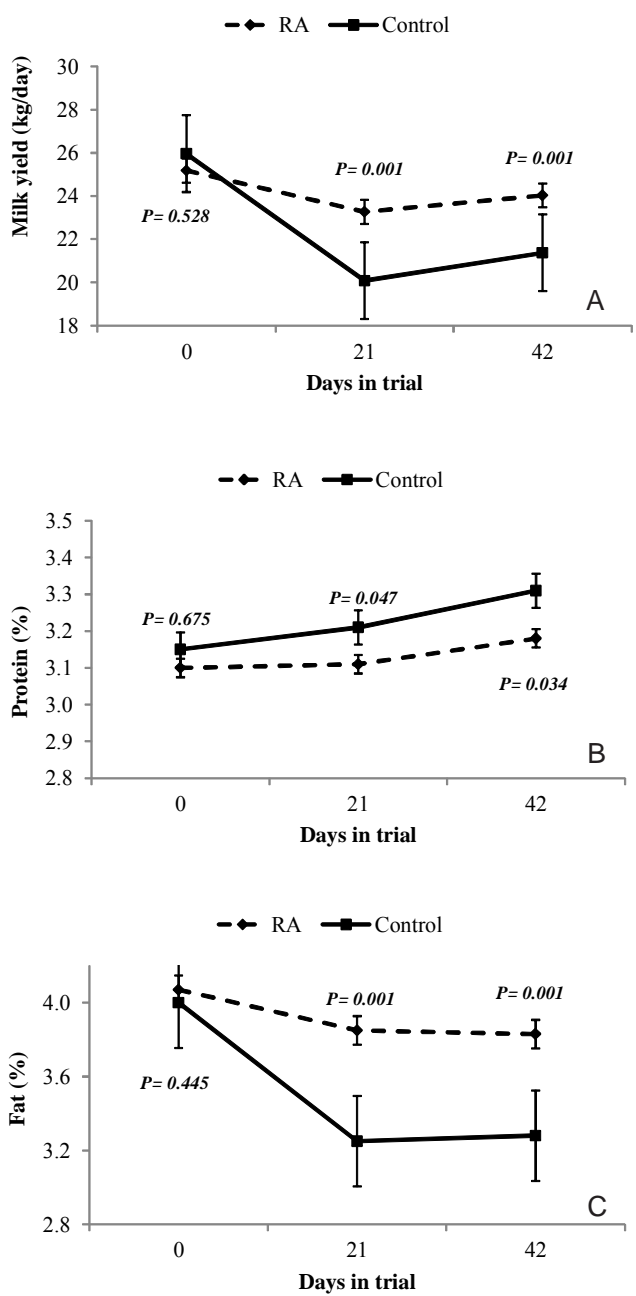

Figure 1. Milk yied (A), protein content (B), and fat content $(C)$, in function of time according with experimental diets. (Produção de leite (A), teor de proteina (B), e teor de gordura (C) em função do tempo de acordo com as dietas experimentais). starting the $21^{\text {st }}$ days of supplementation $(p<0.05)$ for the control diet which remained until the $42^{\text {nd }}$ day of supplementation (table IV).

The time RA supplementation influenced $(p<0.05)$ hemoglobin concentration, MCV, the absolute values of lymphocytes, monocytes and basophils, fibrinogen concentration and neutrophil / lymphocyte ratio.

\section{BLOOD METABOLITES}

It was observed interaction $(p<0.05)$ time effects of supplementation with RA on the concentration of urea, blood urea nitrogen (BUN), and alkaline phosphatase (AP). The concentration of GGT and total protein were affected $(\mathrm{p}<0.05)$ only for the time of supply of RA (table V).

Dosages of urea and blood urea nitrogen were initially higher in animals with diet RA were similar at 21 days lower at 42 days when compared to control diet, characterizing a reduction over time (figure $\mathbf{2 A}$ and $\mathbf{2 B}$ ). Alkaline phosphatase had the highest concentration over time for control diet differed significantly from RA diet for 42 days (figure 2C).

\section{DISCUSSION}

\section{Performance}

The reduction in DMI observed for cows fed RA may be related to the antimicrobial ability of the additive and the possible selection of propionate-producing bacteria in the rumen. Propionate can be produced and absorbed at very high rates and very rapidly taken up by the liver, where it is a major fuel used to produce glucose. However, when propionate is absorbed faster than it can be utilized to produce glucose in the liver, it will likely be oxidized, generating ATP and a satiety signal to the brain (Allen, 2000). The reduction of DMI observed contrasts with most of the effects reported in the literature for the supplementation of essential oils and is similar to 
Table IV. Red blood cells and white blood cells counts. (Contagem sanguineas de células vermelhas e brancas).

\begin{tabular}{|c|c|c|c|c|c|c|}
\hline & \multicolumn{2}{|c|}{ Diet $^{1}$} & \multirow[t]{2}{*}{ SEM } & \multicolumn{3}{|c|}{$p$ value } \\
\hline & Control & RA & & RA & Time & RA*Time \\
\hline Erythrocytes, $10^{6} / \mathrm{mm}^{3}$ & 6.07 & 6.24 & 0.10 & 0.135 & 0.437 & 0.402 \\
\hline Haematocrit, \% & 27.55 & 28.02 & 0.44 & 0.395 & 0.164 & 0.564 \\
\hline Haemoglobin, g/dL & 8.39 & 8.40 & 0.13 & 0.972 & 0.012 & 0.719 \\
\hline $\mathrm{MCV}$ & 44.96 & 45.04 & 0.33 & 0.939 & $<0.001$ & 0.998 \\
\hline $\mathrm{MCH}, \mathrm{pg}$ & 13.907 & 13.61 & 0.12 & 0.889 & 0.419 & 0.235 \\
\hline $\mathrm{MCHC}, \mathrm{g} / \mathrm{dL}$ & 29.97 & 29.91 & 0.32 & 0.030 & $<0.001$ & 0.452 \\
\hline Leucocytes $/ \mathrm{mm}^{3}$ & 16622 & 14333 & - & 0.454 & 0.374 & 0.103 \\
\hline Neutrophils $/ \mathrm{mm}^{3}$ & 3636 & 3938 & - & 0.453 & 0.099 & 0.373 \\
\hline Lymphocytes/mm³ & 7279 & 7184 & - & 0.793 & $<0.001$ & 0.683 \\
\hline Eosinophils $/ \mathrm{mm}^{3}$ & 1540 & 1066 & - & 0.024 & 0.059 & 0.044 \\
\hline Monocytes $/ \mathrm{mm}^{3}$ & 473 & 554 & - & 0.517 & $<0.001$ & 0.073 \\
\hline Basophils $/ \mathrm{mm}^{3}$ & 62 & 44 & - & 0.452 & 0.002 & 0.589 \\
\hline Platelets (x1000)/mm ${ }^{3}$ & 462877 & 439256 & - & 0.437 & 0.063 & 0.059 \\
\hline Fibrinogen, mg/dL & 49.66 & 43.00 & - & 0.198 & 0.005 & 0.718 \\
\hline Neut/Lymph & 0.66 & 0.68 & 0.05 & 0.786 & $<0.001$ & 0.410 \\
\hline
\end{tabular}

${ }^{1}$ Supplement of $2 \mathrm{~g} /$ day of ricinoleic acid from of castor oil (Ricinus communis L.) per animal/day in total diet; $\mathrm{MCV}=$ corpuscular volume; $\mathrm{RA}=$ Ricinoleic acid; $\mathrm{MCH}=$ mean corpuscular haemoglobin; $\mathrm{MCHC}=$ mean corpuscular haemoglobin concentration.

effect reported for the use of ionophores.

Tassoul e Shaver (2009) observed that cows in early lactation, supplemented with commercial mixture of essential oils $\left(\right.$ CRINA $\left.^{\circledR}\right)$, also presented a reduction of DMI. The authors attributed this reduction to the low palatability of the diet given by CRINA $^{\circledR}$. Benchaar et al. (2007) reported,

Table V. Blood metabolites. (Metabólitos sanguíneos).

\begin{tabular}{|c|c|c|c|c|c|c|}
\hline & \multicolumn{2}{|c|}{ Diet $^{1}$} & \multirow[t]{2}{*}{ SEM } & \multicolumn{3}{|c|}{$p$ value } \\
\hline & Control & RA & & RA & Time & RA*Time \\
\hline Urea, mg/dL & 38.05 & 35.48 & 0.99 & 0.230 & $<0.001$ & $<0.001$ \\
\hline Blood urea nitrogen, mg/dL & 20.54 & 19.16 & 0.53 & 0.230 & $<0.001$ & $<0.001$ \\
\hline Total protein, g/dL & 8.77 & 8.82 & 0.10 & 0.793 & $<0.001$ & 0.605 \\
\hline AST, UI/L & 84.17 & 89.14 & 2.56 & 0.263 & 0.057 & 0.615 \\
\hline$A L P, U I / L$ & 87.23 & 61.00 & 9.21 & 0.098 & $<0.001$ & 0.001 \\
\hline GGT:UI/L & 30.63 & 32.73 & 1.45 & 0.455 & 0.015 & 0.950 \\
\hline
\end{tabular}


however, that adding CRINA $^{\circledR}$ does not influence DMI in cows in later stages of lactation.

Benchaar et al. (2006) evaluated a factorial experiment, the effect of monensin,
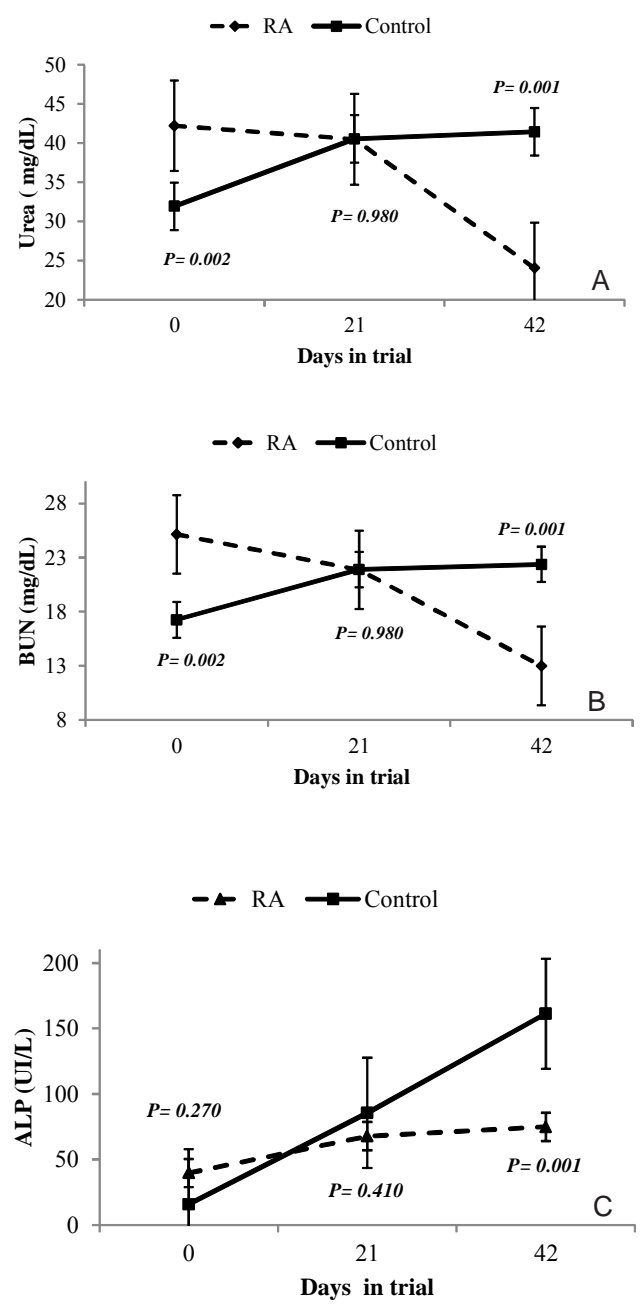

Figure 2. Urea (A), blood urea nitrogen (B), and alkaline phosphatase (C), in function of time according with experimental diets. (Uréia plasmática (A), nitrogênio ureico plasmático (B) e fosfatase alcalina (C), em função do tempo de acordo com as dietas experimentais). and a blend of essential oils. The results suggest an interaction between treatments for dry matter intake. The essential oil increased dry matter intake when supplemented with monensin and reduced when supplemented alone.

The results described in the literature on the influence of essential oils on the DMI, are inconclusive and unsafe due to the fact that commercial products are composed of mixtures of various plant extracts, moreover the data presented by RA are more satisfactory and concrete due the fact that the final product is composed of only the fatty acids of castor oil and its reducing effect on DMI, has already been reported by (Gandra et al., 2012).

The increase in milk yield showed by to diet supplemented with RA may be related to the change in ruminal fermentation profile caused by antimicrobial properties of the supplement. Kung et al. (2008) also reported that supplementation CRINA ${ }^{\circledR}$ increases milk yield. The decrease in DMI associated with an increase in FCM suggests an increased productive efficiency, as observed by (Tassoul e Shaver, 2009).

There was an increase in FCM and fat yield, without influencing the milk fat content. These data corroborate to Kung et al. (2008) that obtained fat yields of 1.24 and $1.13 \mathrm{~kg} /$ day and FCM 38.2 and 35.5 $\mathrm{kg} /$ day for the control and essential oil, respectively.

Kung et al. (2008) observed in in vitro assays, adding that CRINA ${ }^{\circledR}$ in normal doses (1g/animal/day) decreased the molar proportion of acetate, butyrate and valerate, with increased propionate. With higher doses (3g/animal/day) there was a decrease in the molar ratio of propionate, associated with an increase of acetate, butyrate and valerate. The milk fat yield observed in this study suggests the same mechanism associated with increased of milk fat yield reported by Kung et al. (2008) at high doses CRINA $^{\circledR}$. However, when analyzing the data DMI and milk yield the mechanism of 
increased fat yield which best explains the data shown is the increase in milk fat content associated with decreased in partial biohydrogenation and inhibition of the production of C18: 1 trans-10.

The decreased in milk protein yield from animals supplemented associated with the effects observed for urea and blood urea nitrogen indicated, unlike suggested by McIntosh et al. (2003) for a commercial mixture of essential oils. Supplementation with RA may have increased the rate of deamination of amino acids, because there was no increase in milk protein content. According Gandra et al. (2009), monensin in diets for lactating cows can increase levels of blood urea nitrogen. This increase is a result of the higher concentration of undegraded protein in the rumen it reaches the small intestine. These non-essential amino acids absorbed may be used as a substrate for gluconeogenesis, so that the deaminations lead to higher concentrations ofBUN.

\section{HAEMOGRAM AND LEUCOGRAM}

For erythrocyte parameters, there was no significant difference between diets, regardless of the time of supplementation. The means obtained are in agreement with the reference values established by Morris (2006). Hematocrit between $24-46 \%$, erythrocytes from 5 to $10 \times 10^{6} / \mathrm{L}$, hemoglobin between $8-15 \mathrm{~g} / \mathrm{dL}, \mathrm{MCV}$ fL $40-60, \mathrm{MCH}$ pg $11-17$ and MCHC, $30-36 \mathrm{~g} / \mathrm{dL}$ are considered reference values for erythrocyte for dairy cows by (Morris, 2006). Just for MCHC the means obtained in this study were discreetly outside the reference values.

Morris (2006) considered as reference values for white blood cell count in dairy cows (in $\times 10^{3} / \mu \mathrm{L}$ ): 4 to 12 leukocytes, neutrophils 0.6 to 4 ; lymphocytes between 2.5 and 7.5 ; monocytes from 0.025 to 0.84 , eosinophils to $2.4 ; 0.2$ to basophils and neutrophils / lymphocytes ratio between 0.3 and 0.6. Considering these values, with the exception of total leukocytes and neutrophils /lymphocytes ratio, all means of the results obtained in this study are in agreement with the reference values. It was observed a discrete leukocytosis relative increase of neutrophils in relation to leukocytes. Morris (2006), however, reports that a transient leukocytosis associated with neutrophilia and lymphocytosis are common and the resulting temporary mobilization compartment neutrophilic marginal, due to the physiological release of adrenaline under stress, excitement, anxiety or exercise, which can be explained by the act to blood sampling in animals.

The results obtained for the counts of red and white blood cells this trial clearly show that RA is safe for use in dairy cattle herds without compromising the health and welfare of animals acting efficiently and evident only modulates rumen fermentation.

\section{Blood METABOLITES}

The urea and BUN values observed in this study are within the reference values cited by (Rebhun e Guard, 200). For urea and blood urea nitrogen, values were observed for diets with RA, suggesting increased protein deamination in rumen. This decrease in the concentrations of urea and BUN supplemented with RA is consistent with the results obtained by (Gandra et al. 2012).

For total protein, Cozzi et al. (2011) recommends values between 7.0 to $9.4 \mathrm{~g} /$ $\mathrm{dL}$, depending on season and parity order of cow. In this study, it was observed values of 8.77 and 8.82 for the animals that received control and RA diets, respectively. These values are above the reference values cited by (Rebhun e Guard, 200), but justified by the production of animals.

Carlson (2006), considered reference values of aspartate aminotransferase and ãglutamiltranferase 43 to $127 \mathrm{IU} / \mathrm{L}$ and 15 to $39 \mathrm{IU} / \mathrm{L}$, respectively. The means obtained in this study are in agreement with the reference values established. For alkaline phosphatase the values obtained in this study are close to the values cited by 


\section{GANDRA et al.}

(Rebhun e Guard, 200), which can range from 0 to $400 \mathrm{IU} / \mathrm{L}$.

According Benchaar et al. (2008), several studies have been conducted to evaluate the effects of essential oils on ruminal fermentation. Various essential oils, different doses in different diets resulting in inconsistent data. The response variability is associated with chemical differences that will influence the biological activity of the blend.

Considering the data obtained in this experiment and Gandra et al. (2012), supported in the literature it can be stated that the RA has a promising future in rumi-

\section{REFERENCES}

Allen, M.S. 2000. Effects of diet on short-term regulation of feed intake by lactating dairy cattle. J Dairy Sci, 83: 1598-1630.

AOAC. 2000. Association of Official Analytical Chemists, Official Methods of Analysis. $17^{\text {th }} \mathrm{ed}$. Gaithersburg, MD.

Benchaar, C.; Calsamiglia, S.; Chaves, A.V.; Fraser, G.R.; Colombatto, D.; McAllister, T.A. and Beauchemin, K.A. 2008. A review of plantderived essential oils in ruminant nutrition and production. Anim Feed Sci Technol 145: 209228.

Benchaar, C.; Petit, H.V.; Berthiaume, R.; Ouellet, D.R.; Chiquette, J. and Chouinard, P.Y. 2007. Effects of essential oils on digestion, ruminal fermentation, rumen microbial populations, milk production, and milk composition in dairy cows fed alfalfa silage or corn silage. J Dairy Sci, 90: 886-897.

Benchaar, C.; Petit, H.V.; Berthiaume, R.; Whyte, T.D. and Chouinard, P.Y. 2006. Effects of addition of essential oils and monensin premix on digestion, ruminal fermentation, milk production, and milk composition in dairy cows. J Dairy Sci, 89: 4352-4364.

Carlson, G.P. 2006. Biochemical tests. In: Smith, B.P. Medicina interna de grandes animais. $3^{\mathrm{a}} \mathrm{ed}$. Manole. São Paulo. pp. 389-412.

Coneglian, S.M. 2009. Use of essential oils of castor and cashew diets of cattle. Thesis (PhD in Agronomy). State University of Maringa. nant nutrition, as a modulator of ruminal fermentation promoting increased performance, but more study should be conducted in order to elucidate the precise metabolism rumimal involving deamination rates and production of methane and short chain fatty acid.

\section{CONCLUSION}

The inclusion of $2 \mathrm{~g} /$ day of ricinoleic acid (RA) in diets of dairy cows improved the performance, without any risk to health and welfare of animals, being a promising additive in ruminant nutrition.

Maringá. Brazil.

Cozzi, G.; Ravarotto, L.; Gottardo, F.; Stefani, A. L.; Contiero, B.; Moro, L.; Brscic, M. and Dalvit, P. 2011. Short communication: Reference values for blood parameters in Holstein dairy cows: Effects of parity, stage of lactation, and season of production. J Dairy Sci, 94: 3895-3901.

Dorman, H.J.D. and Deans, S.G. 2000. Antimicrobial agents from plants: antibacterial activity of plant volatile oils. J Appl Microbiol, 88: 308316.

Ferreira, C.M.; Rosa, O.P.S.; Torres, S.A.; Ferreira, F.B.A. and Bernadinelli, N. 2002. Activity of endodontic antibacterial agents against selected anaerobic bacteria. Braz Dental J, 13: 118-122. Gandra, J.R.; Rennó, F.P.; Silva, L.F.P.; Freitas Jr., J.E.; Maturana Filho, M.; Gandra, É.R.S.; D'Ângelo L.S. and Araújo, A.P.C. 2009. Blood parameters of dairy cows fed different dietary sodic monensin levels. Rev Bras Saúde Prod, 10: 115-128.

Gandra, J.R.; Nunes Gil, P.C.; Cônsolo, N.R.B.; Gandra, E.R.S. and Gobesso, A.A.O. 2012. Addition of increasing doses of ricinoleic acid from castor oil (Ricinus communis L.) in diets of Nellore steers in feedlots. J Anim Feed Sci, 21: 566-576.

Gandra, J.R.; Rennó, F.P.; Freitas Junior, J.E.; Santos, M.V.; Silva, L.F.P. and Araújo, A.P.C. 2010. Performance and composition of the protein fraction of milk in cows supplemented 


\section{PERFORMANCE OF SIMMENTAL DAIRY COWS WITH CASTOR OIL RICINOLEIC ACID}

with different levels of monensin in diets. Rev Bras Zootecn, 42: 239-241.

International Dairy Federation - IDF. 1996. Whole milk. Determination of milk fat, protein and lactose content Guide for the operation of mid-infra-red instruments. International Dairy Federation. Brussels. (IDF Standard 141 B). 12 pp.

Kung, L.; Williams, P.; Schmidt, R.J. and Hu, W. 2008. A blend of essential plant oils used as an additive to alter silage fermentation or used as a feed additive for lactating dairy cows. J Dairy Sci, 91: 4793-4800.

Mclntosh, F.M.; Williams, P.; Losa, R.; Wallace, R.J.; Beever, D.A. and Newbold, C.J. 2003. Effects of essential oils on ruminal micro- organisms and their protein metabolism. Appl Environ Microbiol, 69: 5011-5014.

Morris, D.D. 2006. Alterações no éritron. In: Smith, B.P. Medicina interna de grandes animais. $3^{\mathrm{a}} \mathrm{ed}$. Manole. São Paulo. pp. 415-419.

NRC. National Research Council. 2001. Nutrient requirements of dairy cattle. $7^{\mathrm{a}}$ ed. National Academic Press. Washington, D.C. 381 pp.

Rebhun, W.C. and Guard, C. 2000. Diseases of dairy cow. Rocca. São Paulo. 642 pp.

Tassoul, M.D. and Shaver, R.D. 2009. Effect of a mixture of supplemental dietary plant essential oils on performance of periparturient and early lactation dairy cows. J Dairy Sci, 92: 17341740 . 